\title{
Literatuurgeskiedskrywing en diskoers: die 'begin' van die Afrikaanse letterkunde
}

\begin{abstract}
In this article Afrikaans literary historiography is analysed by means of the discourse-analytical tradition associated with the name of Michel Foucault. Approaching Afrikaans literary historiography as a discursive formation makes it possible to argue that the nationalist-teleological character of the historiography has led to the marginalisation of a mumber of Afrikaans literary traditions. This argument then identifies the reclamation of these marginalised literary traditions as one of the most pressing lasks of Afrikauns literary historiography. Foncauldian discourse theory is finally' used with reference to the alkernative conception of history which accompanies it to suggest a solution to the problem of these marginalised Afrikaans literary traditions.
\end{abstract}

\section{Inleiding}

Die afyelope dekade of wat het literêr-teoretiese en sosiopolitieke woelinge daartoe bygedra dat besinning en debat oor literatuurgeskiedskrywing een van die lewendigste gespreksterreine op die Suid-Afrikaanse letterkundige toneel geword het.

Wat die Afrikaanse letterkunde betref, was die Marxistiese literatuurbenadering wat in die vroee tagtigerjare aan die Universiteit van Wes-Kaapland ontwikkel is, heel moontlik dié duidelikste teken van 'n stygende belangstelling in literatuurgeskiedkundige kwessies. Twee van die belangrikste tekste wat uit hierdie ontwikkeling voortgekom het, is (onder vele ander) Gerwel (1983) en Coetzee (1990). 'n Simposium oor Suid-Afrikaanse letterkundenavorsing gereël deur die Raad vir Geesteswetenskaplike Navorsing in samewerking met UNISA vir 11 en 12 Oktober 1982, was eweneens een van die eerste tekens van 'n literêr-kritiese oplewing binne meer 'ortodokse' kringe (vgl. Malan, 1984). Hierop volg 'n aantal werkswinkels en kongresse oor literatuurgeskiedskrywing (vgl. Malan, 1986; Gray, 1986 en Botha, 1988). Die reeks jaaroorsigte SA Literature 
Lıteratuur wat vanaf 1982 onder redakteurskap van Francis Galloway begin verskyn, getuig ook van hernieude belangstelling in literatuurgeskiedskrywing.

Hierdie artikel wil 'n bydrae tot dié studieveld maak deur die implikasies van 'n Foucaultiaanse diskoersanalitiese benadering tot die geskiedskrywing van spesifiek die Afrikaanse letterkunde te verken

Ofskoon 'n suiwer epistemologiese impuls genoegsame regverdiging mag wees vir so 'n onderneming, is die deurslaggewende prikkel in die geval van hierdie studie die misnoeë en ontevredenheid wat die afgelope paar jaar uitgespreek is oor - onder meer - die wyse waarop die geskiedskrywing van die Afrikaanse letterkunde tot op hede bedryf is. Hierdie kritiek strek vanaf teoreties-metodologiese besware (vergelyk Cloete, 1982) tot ideologies-politieke reaksies (vergelyk Coetzee, 1990; Olivier, 1989).

Een van die sterkste stromings in hierdie kritiek beskuldig die bestaande Afrikaanse literatuurgeskiedskrywing van gedienstigheid ten opsigte van die ideologie en instelling van die Afrikanernasionalisme, ${ }^{l}$ en bepleit gevolglik die noodsaak van ' $n$ ander konseptuele basis vir die geskiedskrywing van die Afrikaanse letterkunde. Dit is hierdie stroming in die kritiek op die Afrikaanse literatuurgeskiedskrywing en veral die gepaardgaande voorstelle vir alternatiewe benaderings tot die Afrikaanse literatuurgeskiedskrywing, spesifiek twee van die 'radikaler' voorstelle - Coetzee (1990) en Van Vuuren (1991) (vgl. ook Botha, 1986 en Malan, 1990) - wat as vertrekpunt vir hierdie artikel dien.

Die diskoersanalise word egter eerstens diagnosties aangewend om die ontstaansbodem van die huidige ontevredenheid te belig. Die fokus val in hierdie opsig op die rol wat die konseptualisering van die 'begin' van die Afrikaanse letterkunde in die literatuurgeskiedskrywing gespeel het. Die analise verbind die probleem uiteindelik aan die eensydig nasionalisties-teleologiese ingesteldheid van die geskiedskrywing.

Terwyl hierdie diagnose die maatstaf skep waaraan die aanvaarbaarheid van alternatiewe gemeet kan word, blyk die werklike waarde van 'n diskoersanalitiese benadering eers wanneer nóg ' $n$ alternatiewe konsepsie van die 'begin' van die Afrikaanse letterkunde - gebaseer op enkele Foucaultiaanse konsepte - naas die bogenoemde alternatiewe geplaas word.

1 Dit is nic mocilik om voorbeclde te vind waar hicrdic opinic uitgespreck word nic Dic volgende is maar 'n paar voorbcelde: Coctzec (1990), Van Vuuren (1991), Olivier (1989), Gouws (1992). 


\section{Diskoersanalise}

Die diskoersanalise vorm 'n uitgebreide studieveld waarby ' $n$ verskeidenheid dissiplines soos die linguistiek, antropologie, geskiedenis, letterkundestudie en filosofie betrokke is en waarin verskeie teoretiese en metodologiese tradisies verteenwoordig word, vergesel van 'n nog groter verskeidenheid soorte analises, studieobjekte en uitgangspunte. Hierdie artikel is nie nog 'n bydrae tot hierdie studieveld of 'n ontwikkeling daarvan as sodanig nie, maar gebruik enkele geselekteerde konsepte en perspektiewe daaruit wat kan help om lig te werp op die tersaaklike probleem.

Vir die doel van die hieropvolgende betoog word daar hoofsaaklik aansluiting gevind by die ontwikkeling van die diskoersanalise deur Michel Foucault, veral soos verteoretiseer in The Archaeology of Knowledge (1972). Sy benadering tot die diskoersanalise is veral geskik on vir hierdie doel gebruik te word ondat dit gepaard gaan met ' $n$ radikale geskiedsfilosofiese vraagstelling. Dit is ook nie geheel en al vreemd aan die Afrikaanse letterkundige kritiek nie, aangesien 'n Foucaultiaanse benadering reeds gebruik is om die Afrikaanse Marxistiese teksopvatting diskoersanalities te bestudeer (De Jong, 1989).

Dit is uit Foucault (1972) baie duidelik dat sy werk gebaseer is op 'n sentrale leerstelling van die diskoersanalise, naamlik dat die betekenis van ' $n$ uiting nie afhang van 'n gewaande verbintenis met die werklikheid nie, maar van die gebruiksomgewing waarin dit verskyn (Foucault, 1972:89-92; vergelyk ook Macdonell, 1986:1).

Foucault se werk het hierdie leerstelling egter ingeskakel by die poststrukturalistiese projek wat gerig is op die bevraagtekening van die metafisiese begronding van bestaande konsepsies van onder meer geskiedenis en geskiedskrywing, die verhouding tussen die subjek en betekenis en die subjeksrol. Hierdie inskakeling word vermag deur die 'gebruiksomgewing' te konseptualiseer as 'n 'diskursiewe formasie'.

'n Diskursiewe formasie bestaan in die eerste plek as 'kennis,' dit wil sê as 'n versameling stellings oor die werklikheid wat gepaard gaan met 'n aanspraak op 'waarheid.' Die Afrikaanse literatuurgeskiedskrywing maak byvoorbeeld aanspraak daarop dat dit 'n ware voorstelling verteenwoordig van die ontwikkeling van die Afrikaanse letterkunde.

Die belangrikste manier waarop Foucault die legitimiteit van die tradisionele Westerse kennisinstelling bevraagteken, is deur die interafhanklikheid van kennis en mag te ondersoek en te beklemtoon. In sy vroeë werk, waarvan The Archaeology of Knowledge deel uitmaak, figureer die magskonsep egter glad nie, alhoewel dit implisiet teenwoordig is (vgl. Foucault, 1980:115). Die magskonsep kom ook nie eksplisiet ter sprake in hierdie artikel nie wat derhalwe grootliks 
binne die raamwerk van die 'vroeë' Foucault bly, anders as die geval met De Jong (1989).

Die invloed van mag spreek egter duidelik uit die patroonmatigheid van die uitings waaruit diskursiewe formasies bestaan soos die volgende: tematiese ooreenkomste, reèlmatige verskille en 'n vasgestelde sprekersposisie of -rol (vergelyk De Jong, 1989:9-10 vir 'n vollediger uiteensetting). 'n Diskursiewe formasie speel dus in die eerste plek 'n konstituerende en regulerende rol. Dit 'skep' byvoorbeeld ubjekte soos waansin, die roman, ensovoorts (vergelyk Foucault, 1972:33), asook die reêls waarvolgens uitings met betrekking tot hierdie objekte gegroepeer word: psigiatrie, literêre kritiek, geskiedskrywing (vergelyk Foucault, 1972:34; De Jong, 1989:10).

Hierdie 'skeppende' rol van diskursiewe formasies het egter ook 'n ander, eksklusiewe, sy: 'strategiese keuses' bepaal watter van die objekte en uitings wat diskursief moontlik gemaak word, wel in die diskursiewe formasie opgeneem word:

A discursive formation does not occupy therefore all the possible volume that is opened up to it of right by the systems of formation of objects, its enunciations, and its concepts; it is essentially incomplete, owing to the system of formation of its strategic choices (Foucault, 1972:67; vgl. ook Foucault, 1977:199).

Binne so 'n perspektief word enige subjek, asook die subjek wat die uiting voortbring, voorafgegaan deur 'n komplekse struktuur (wat meer insluit as die begrip konteks) wat uitings binne die raanwerk van die diskursiewe formasie radikaal relativeer ten opsigte van enige moontlike gewaande intensies, bedoelde betekenisse of begeerde doelwitte wat die subjek mag gehad het.

Die toepassing van hierdie perspektief op die historiese ontwikkeling van kennis oor 'n objek, soos byvoorbeeld die Afrikaanse letterkunde, vind noodwendig 'n neerslag in 'n siening wat afwyk van die normale of tradisionele. In plaas van 'n liniêre ontwikkeling onder die beheer van 'n rasionele menslike subjek, vergesel deur idees oor die progressiewe verbetering van die letterkunde ('vernuwing') en kennis van die letterkunde (literatuurgeskiedenis), kry ons ' $n$ 'argeologiese' visie op historiese verandering waarin afgeslote of diskontinue lae mekaar opvolg.

Nethersole (1987:7) beskryf die oorgang vanaf ' $n$ historisistiese tot 'n argeologiese benadering soos volg:

The archaeological procedure ... 'implodes', so to speak, history and particularly the causal necessity of history as posited by Historicism by displacing the temporal, linear ordering - common also to all literary history 
writing ... - by a spatial order in the shape of taxonomies, trajectories, topologies etc.

'Argeologie' en 'diskontinuiteit' sluit aan by begrippe soos différance, strukturele kousaliteit en la pensée sauvage in die denke van anti-humanistiese denkers soos Jacques Derrida, Louis Althusser en Claude Lévi-Strauss en die dekonstruksie en desentrering wat daarmee bewerkstellig moes word. ${ }^{2}$

Diskontinuïteit enkapsuleer 'n visie op die historiese gang wat die dominante kontinuiteitsbeginsel waarop geskiedskrywing hoofsaaklik tot op hede plaasgevind het, verplaas. Dit problematiseer begrippe wat hierdie beginsel vergesel begrippe soos oorsprong, ontstaan, ontwikkeling, evolusie, gees, identiteit en tradisie (Foucault, 1972:21-22). Foucault betoog dat hierdie begrippe deel vorm van 'n androsentriese of metafisiese historiese perspektief. Hierdie perspektief word gekenmerk deur die soeke na 'n oorsprong of ' $n$ begin, die terugvoer van betekenis na 'n sentrale subjek, die aantoon van die doel wat 'n historiese ontwikkeling moet verwerklik en die gebruikmaking van 'n oorsaak-gevolg-model.

Die hieropvolgende analise van die Afrikaanse literatuurgeskiedskrywing in terme van hierdie uiteensetting illustreer in die eerste plek die diskursiewe reëlmatigheid van die geskiedskrywing. Die oogmerk in hierdie opsig is om sodoende aan te sluit by die anti-nasionalistiese stroming waana reeds verwys is. Hierdie analise dien dan as agtergrond vir die daaropvolgende beskrywing van Afrikaanse letterkundige tradisies wat weens 'n wisselwerking tussen letterkunde- en klasse-, rasse- en kunsdiskoerse nie in die diskoers van die Afrikaanse literatuurgeskiedskrywing opgeneem is nie. Hiema word die Foucaultiaanse diskontinuiteitsbeginsel aangewend on 'n nuwe status vir hierdie gemarginaliseerde tradisies en gevolglik die Afrikaanse letterkunde te bepleit.

\section{Die Afrikaanse literatuurgeskiedskrywing as diskoers}

Om aan te toon hoe die Afrikaanse literatuurgeskiedskrywing as 'n diskursiewe formasie funksioneer, word daar vervolgens gefokus op die tema, die 'begin van die Afrikaanse letterkunde'. Die Afrikaanse literatuurgeskiedskrywing word in hierdie opsig in drie diskursiewe 'eenhede' gegroepeer, naamlik 'n pioniersgroep, 'n Hollandse periode en 'n 'ensiklopediese' tradisie. ${ }^{3}$

2 Young (1990 53-62) sc bespreking van dic verband tussen Althusser sc konscp van strukturele kousalitett en dic alternatiewe geskicdenisbenadering wat daarmec gepaard gaan, naamlik 'n differenfial history, dui dic nouc verwantskap van dic Foucaultiaanse historicse visic met hierdic tradisic baic duidelik aan.

3 Dic volgende literatuurgeskicdkundige tekstc is nic in aanmerking geneem vir hierdic studic nic, hoofsaaklik omdat dit dic betoog te uitgebreid sou maak: Nienaber (1960), Coctzec en Hattingh (1951), Cloctc (1980) on Van Rensburg (1971) Dic Afrikaansc drama- 
Die eerste eenheid word gevorm deur Van Niekerk (1920), Schoonees (1927), Pienaar (1931a) en Von Wielligh (1922 en 1925). Alhoewel hierdie tekste op verskillende onderwerpe en periodes konsentreer, soos byvoorbeeld of die letterkunde van die Eerste óf die Tweede Taalbeweging, of op ' $n$ enkele genre soos prosa of poësie, stem hulle ooreen in dié opsig dat almal, indien dit nie daarop toegespits is nie, ' $n$ uiteensetting van die Eerste Taalbeweging insluit. Die geskiedenis van die Afrikaanse letterkunde word dan ook nie verder teruggevoer as 1875 en die stigting van die Genootskap van Regte Afrikaners nie. Die tekste kom ook ooreen in dié opsig dat die Afrikaanse letterkundige tradisie eenlynig gekonsipieer word: slegs een gebeurtenis en die ontwikkeling wat daaruit voortvloei - die stigting van die GRA - word tot die oorsprong van die Afrikaanse letterkunde gereken.

Dié kenmerk van hierdie tekste kan verklaar word deur die feit dat hulle 'n rol gespeel het in die Tweede Taalbeweging en die stryd wat om en deur die Afrikaanse taal gewoed het. Die doelwit van hierdie stryd was die politieke en kulturele emansipasie van die Afrikaner as 'n selfstandige (etnies-nasionalistiese) entiteit. Een van die belangrikste kwessies, bo en behalwe letterkunde, waarmee hierdie tekste derhalwe heel verstaanbaar gemoeid was, is die verkondiging en vestiging van 'n band tussen ' $n$ Afrikaanse volk, die Afrikaanse taal en die Afrikaanse letterkunde.

Die beklemtoning van die spontaneiteit van hierdie ontwikkeling skep die indruk van 'n organiese band tussen volk en letterkunde, soos in die volgende voorbeeld, waarvan daar talle in die tekste voorkom:

Dit is wonderlik: so gou daar ' $n$ volksontwaking kom, dan sien ons baie gedigte en rympies in die dagblaaie en in tydskrifte verskyn, die gevoel om uiting te gee wat in die hart opborrel, word onweerstaanbaar" (Von Wielligh, 1922:109).

Op 'n ander plek skryf Von Wielligh (1925:53): "En so was daar in Die Patriot en Ons Klyntji nog meer gloeiende spatsels uit die smeltkroes wat van Afrikaners 'n volk gemaak het." Vergelyk ook Pienaar (1931b:212):

Die heerlikste vrug egter van al die leed en stryd was die geboorte van 'n eie literaire kuns in die volkstaal van Suid-Afrika - in die woorde van die onvergetelike President Steyn 'so heerlik as die geluid van die eerste reëndruppels na ' $n$ langdurige droogte.'

geskiedskrywing het ook buite rekening gebly. Ek is egter daarvan oortuig dat die insluiting van hierdie tekste nie die kem van dic betoog sal raak nic 
Selfs Opperman (1939:55) sluit hierby aan deur te verwys na die "onaflanklikheidsgees" van die Afrikaner: "... 'n houding wat groei uit en on die volk, hom in dade uit en sporadies in die letterkunde."

Nog 'n manier waarop die behoefte aan selfdefinisie in hierdie tyd bevredig is, is deur middel van uitsluiting. Dit het onder meer neergekom op die beklemtoning van 'n afstand van en 'n breuk met die Nederlandse taal en kultuur. Daarom is dit verstaanbaar dat die Afrikaanse letterkunde vir hierdie tekste moes begin met die Eerste Taalbeweging en die Genootskap van Regte Afrikaners en dat Nederlands slegs op die periferie as 'n taalkwessie figureer.

Die tweede diskursiewe eenheid wat vir die doel van my betoog onderskei word, kom as 'n soort logiese reaksie op die eerste eenheid, en word gevorm deur Elizabeth Conradie se Hollandse skrywers uit Suid-Afrika. Deel l. 1652 1875 (1934), en haar betoog dat ook die tekste wat in Suid-Afrika in Hollands geskryf is tot die geskiedenis van die Afrikaanse letterkunde behoort. Die lang polemiek wat hierdie studie ontlok, maak ook deel uit van hierdie diskursiewe eenheid of moment, ten spyte van die uiteenlopende opinies wat daarin uitgespreek word. ${ }^{4}$ As diskursiewe gebeurtenis speel polemieke soos hierdie 'n rol by die proses van "differensiasie" (De Jong, 1989:10), 'n diskursiewe meganisme waardeur die objek van 'n diskursiewe formasie ontwikkel word.

Conradie se konsepsie van die begin van die Afrikaanse letterkunde kan weer eens deels teruggevoer word na 'buite-literêre' gebeurtenisse, in hierdie geval die persepsie dat daar 'n beloefte bestaan het vir toenadering tussen die Afrikaanse en Nederlandse kultuurgroepe. Hierdie proses kom veral op dreef nadat Afrikaans amptelike erkenning as taal ontvang het en die besef posgevat het dat die outonomie van die Afrikaanse subjek minder kwesbaar is (Oppernan, 1939: 29; Nienaber \& Nienaber, 1941:18).

Die gebruiklike benadering tot bogenoemde twee diskursiewe eenhede sou wees om dit 'histories' te benader en in 'n chronologiese reeks te rangskik in ooreenstemming met tradisionele idees omtrent historiese verandering. Net so sou die literatuurgeskiedenisse wat tot die derde diskursiewe eenheid behoort, Kannemeyer (1984), Antonissen (1965) en Dekker (1937), in die eerste plek hiërargies gerangskik kan word en in die tweede plek voorgestel kan word as 'n verbetering op die literatuurgeskiedskrywing van die eerste twee diskursiewe eenhede, byvoorbeeld mel verwysing na die organisasie van die stof.

'n Argeologiese benadering maak dit egter moontlik om ander verbande tussen hierdie literatuurgeskiedenisse te postuleer. In die eerste plek dui die ooreenkoms 
tussen Kannemeyer, Antonissen en Dekker se literatuurgeskiedenisse op 'n diskursiewe verband, ten spyte van verskille ten opsigte van publikasiedattum en inhoud. Die voorstelling van die verhouding tussen hulle as 'n progressiewe verbetering word trouens beskou as 'n diskursiewe meganisme waardeur die skyn van heterogeniteit gehandhaaf word en hou verband met die diskursiewe 'differensiasie' waarna reeds verwys is.

Die ooreenstemmende, byna ritualistiese samevoeging van die nasionalistiesgeînspireerde siening van die begin van die Afrikaanse letterkunde gekoppel aan die geskiederis van die taalbewegings, en die siening wat die 'Afrikaanse letterkunde' terugvoer na die eerste Hollandse voet op Afrikaanse bodem in al drie hierdie mees resente en toonaangewende Afrikaanse literatuurgeskiedenisse (vgl. Dekker, 1937:1; Antonissen, 1965:7; en Kannemeyer, 1984:1; 18), is veral insiggewend in hierdie opsig. ${ }^{5}$ Bo en behalwe 'n aanduiding van 'n diskursiewe formasie, is dit 'n duidelike teken dat die sienings van die begin van die Afrikaanse letterkunde in die eerste twee diskursiewe groeperings wat hierbo ontleed is, versoenbaar is

Binne die nuwe samehang in die literatuurgeskiedenisse van Dekker, Antonissen en Kannemeyer word die belangrikste funksie of betekenis van Conradie se teks, diskursief gesproke, die uitbreiding van die temporele basis van die Afrikaanse letterkunde. Waar die geskiedskrywing van Von Wielligh, Van Niekerk, Sclıoonees en Pienaar blyke gee van die totstandkoming van die subjek van 'n nasionalisties-gelnspireerde Afrikaanse letterkunde, verskaf die 'Hollandse konneksie' 'n temporele dimensie aan hierdie subjek. Dit is hierdie soort van proses waama Malan (1990:36) verwys:

Kenmerkend van ' $n$ ouer metodologiese aanpak was die ... gebruik om teleologiese terugprojeksies van 'n eie wêreldbeeld te doen om 'n tradisie uit die geskiedenis te selekteer

Nienaber en Nienaber (1941) is 'n interessante hibridiese geval in hierdie opsig. Die 'Hollandse konneksie' word in hierdie teks toegelaat as deel van 'n oorsig oor die argumente oor die begin van die Afrikaanse letterkunde, maar 'taal' word uiteindelik gekies as beslissende kriterium sodat hulle die Afrikaanse letterkunde in 1795 laat begin met die "Lied ter Ere van de Swellendamsche en Diverse Andere Helden bij de bloedige Actie aan Muisenberg". Hierdie literatuurgeskiedenis kan by sowel die Van Niekerk- as die Kannemeyer-groepcring ingedeel word, wat moontlik ook die rede is waarom dit nooit hoog aangeskryf is nie. Dit is 'n duidelike aanduiding dat die temporele legitimering van die Afrikaanse letter-

Du Plessis (1986:1) noem die insluiting van die geskiedenis van dic taalbewegings "n tradisie" wat tcruggevocr kan word na S.J. du Toit se Geskidenis fan die Afrikachse Taalbeweging (1909). 
kunde deur die insluiting van Nederlands in die Kannemeyergroepering van meer waarde was.

Nog 'n voordeel van die samevoeging is dat dit me die nasionalistiese enkellynigheid van die historiese perspektief waarop hierdie geskiedskrywing gebaseer is, in die gedrang bring nie. Die samevoeging versterk eerder die enkellynige perspektief deurdat Conradie se Hollandse perspektief ondergeskik gestel word aan die homogene, eenlynige perspektief van die nasionalistiese geskiedskrywing. 'n Uitvloeisel hiervan is die skepping van 'n diskursiewe meganisme wat Nederlandse tekste amper outomaties as minder belangrik merk, byvoorbeeld met verwysing na sekere 'kriteria' - soos 'n 'Afrikaanse gees'.

Met die hulp van 'n diskoersanalitiese benadering word dit dus moontlik on te betoog dat die samevoeging van die "Hollandse konneksie' en die taalbewegings in die Afrikaanse literatuurgeskiedenis 'n diskursiewe aangeleentheid is. Die samevoeging van hierdie twee diskursiewe eenhede, in die vorm van Dekker, Antonissen en Kannemeyer se literatuurgeskiedenisse, kan derhalwe nie gesien word as 'n representasie van wat in die geskiedenis gebeur het nie, soos die literatuurgeskiedskrywers dit sal wil hê nie, maar beklemtoon eerder die konvensionaliteit van hierdie tekste en die perspektiewe wat dit vergesel.

Elke soortgelyke onkritiese gebruik van die frase, '... die Afrikaanse letterkunde begin in 1652 ...', bevat, gesien vanuit 'n argeologiese oogpunt, hierdie komponente as 'n gesedimenteerde basis. Die gebruik van dié frase impliseer dus 'n diskursiewe reiterasie van die historisistiese en gepaardgaande nasionalistiese perspektief daarin opgeslote, dit wil sê van 'n homogene Afrikaanse letterkunde wat iewers as kiem of 'gees' teenwoordig is, wat wortel skiet, groei en geleidelik ontplooi in die rigting van 'n 'volwaardige' letterkunde. Dit is hierdie perspektief wat Kannemeyer se uitdruklike ontkennings van 'n politieke strekking vir sy literatuurgeskiedenis, en kritici soos Olivier (1987 en 1989), Coetzee (1990) en Van Vuuren (1991) se ewe oortuigde aanduiding van die nasionalistiese inslag van sy literatuurgeskiedskrywing, die beste verklaar.

\section{Gemarginaliseerde Afrikaanse tradisies}

Soos vroeër aangedui, word die konstituerende funksie van 'n diskursiewe formasie altyd vergesel deur meganismes ('strategiese keuses') waardeur sekere moontlike uitings uit die diskursiewe formasie geweer word. Die voorafgaande analise maak dit in hierdie verband duidelik dat die twee diskursiewe eenhede wat die produksie van die drie toonaangewende Afrikaanse literatuur-geskiedenisse voorafgegaan het, in 'n groot mate bepaal wat Dekker, Antonissen en Kannemeyer kon geskryf het. 
'n Historiese visie wat grondliggend verskil van die heersende perspektief in die twee diskursiewe eenhede, byvoorbeeld deur die insluiting van letterkunde van ander groepe in die Suid-Afrikaanse samelewing of ander letterkundige vorme, sou baie moeilik uitdrukking gevind het, en as dit wel tot uitdrukking gekom het, sou dit negatief gewaardeer gewees het. Dit is met verwysing na hierdie diskursiewe meganisme dat die randbestaan van 'n aantal Afrikaanse letterkundige tradisies op die vrugbaarste wyse benader kan word.

Belcher (1988) wys byvoorbeeld op die bestaan van 'n lewenskragtige Afrikaanse tradisie op Genadendal waar volgens hom die eerste Afrikaanse roman gepubliseer is, die veelberoemde (maar ongesiene) Benigna van Groenekloof, wat egter nie in die belangrikste Afrikaanse literatuurgeskiedenisse aandag kry nie. In soortgelyke verband dui February (1991) weer die Kreoolse letterkunde van Indonesië, waarvandaan baie van Suid-Afrika se slawebevolking gekom het, aan as 'n belangrike maar geìgnoreerde studieveld

Meer onlangs is daar 'n baie duidelike stem gehoor van swart Afrikaanse skrywers in Wes-Kaapland - skrywers wat die gevestigde Afrikaanse letterkunde met verdrukking assosieer en slegs uitdrukkingsmoontlikhede sal aanvaar waar "... jy jou op jou kompromislooste (sic) ..." kan uitdruk (Willemse, s.a.:76). Hierdie tendens word dan ook organies vergesel deur ' $n$ program om minder gewaardeerde stemme van die verlede te herwin sonder inagneming van enige sanksies wat die gevestigde Afrikaanse letterkundige tradisie ten opsigte van so 'n program mag uitoefen (vgl. Willemse, 1992).

Die verdwyning van 'n volkskundige perspektief uit die Afrikaanse letterkunde is nog ' $n$ voorbeeld van die proses van marginalisering. Die volkskundige perspektief was wat die letterkundige sy daarvan betref, veral soos vergestalt in die werk van Abel Coetzee, ${ }^{6}$ die slagoffer van die triomf van die elitistiese estetiese ideologie van N.P. van Wyk Louw en die Dertiger-beweging. Die ınarginalisering en uiteindelik verdwyning van hierdie perspektief het belangrike fasette van die letterkundige ervaring, soos oraliteit, uit die Afrikaanse letterkunde verwyder. ${ }^{7}$

'n Kontemporêre ontwikkeling in die Afrikaanse letterkunde wat verband hou met die eksklusiwiteit van die Afrikaanse letterkunde is die doelbewuste beweging wég van die aanvaarde en aanvaarbare literêre weë soos vergestalt in die publi

6 Coetzee (1960:22-23) gec blyke van die mate waarin hicrdic diskocrs in dic ecrste twec dekades van dic huidige ecu uitgedy het.

7 Coctser (1992) se pleidooi vir 'n herwaardering van die orale komponent van die Afrikaanse letterkunde is in hicrdic opsig ' $n$ duidelike aanduiding van die mate waarto hicrdie uitsluiting dic Afrikaanse tradisic verskraal het Vergelyk ook Willemse (1990:374). 
kasieproses van Koos Kombuis se Afrikaans my darling (s.a.) wat "... weggegooi eerder as gepubliseer ..." word as teken van die verwerping van die Afrikaanse letterkundige tradisie soos tans gekonstitueer (Jordaan, 1993:18)

Die belangrikste afleiding wat hier uit die voorafgaande gemaak word, is dat enige voorstel vir ' $n$ alternatiewe benadering tot die geskiedskrywing van die Afrikaanse letterkunde juis vanuit die marges van die Afrikaanse letterkunde moet begin. Sodanige benadering moet ook, benewens 'n verrekening van die nasionalistiese bepaling van die Afrikaanse letterkunde, 'n herbesinning oor die status van gemarginaliseerde stromings ten opsigte van 'die Afrikaanse letterkunde' insluit.

Vanuit die oogpunt van die literatuurgeskiedskrywing, beteken dit dat die belangrikste taak vir die Afrikaanse letterkunde die skepping is van 'n perspektief waarin die konsepsies van 'n aantal uiteenlopend verskillende stromings of groeperings in die Afrikaanse letterkunde geakkommodeer kan word.

\section{Voorstelle vir inklusiewe benaderings}

Die twee voorstelle vir 'n alternatiewe benadering tot die geskiedenis van die Afrikaanse letterkunde, Coetzee (1990) en Van Vuuren (1991), wat nou met betrekking tot die voorafgaande analise aan die bod kom, openbaar albei ' $n$ bewustheid van 'n behoefte om die diskursiewe reikwydte van die Afrikaanse literatuurgeskiedskrywing uit te brei deur die insluiting van voorheen uitgeslote diskoerse. Daar is egter belangrike verskille tussen hulle met betrekking tot die manier waarop daar gestalte gegee word aan hierdie oortuiging.

Reg aan die begin van sy studie stel Coetzee (1990: 7) dit as sy standpunt dat "... die Afrikaanse letterkunde nie 'n aparte geskiedenis [kan] hê nie: dit moet deel word van 'n nasionale kultuur, 'n nasionale letterkunde". Om hierdie doelwit te bereik, stel hy voor dat die geskiedenis van die Afrikaanse letterkunde vanuit 'n histories-materialistiese perspektief benader word. So 'n perspektief beteken dan

... die verskuiwing van die aandag vanaf die suiwer en onaanraakbaar estetiese van ' $n$ teks (soos dit gekanoniseer is en dus buite die geskiedenis geplaas is) na ander aspekte van dié teks, of na ander tekste wat moontlik meer te sê het binne 'n nasionale bewussyn (Coetzee, 1990:7).

Die ander tekste wat Coetzee betrek, is nie ander literère tekste of diskoerse soos die gemarginaliseerde Afrikaanse tradisies waarna hierbo verwys is nie, maar is hoofsaaklik geskiedkundige tekste. Eweneens kom die "ander aspekte van die Afrikaanse literêre teks" waana Coetzee verwys, hoofsaaklik neer op die studie van die rol wat hierdie tekste volgens hom gespeel het by die ontwikkeling van die Afrikanemasionalisme 
Verder bestaan Coetzee se benadering uit die herorganisasie van die bestaande versameling Afrikaanse literêre tekste. Die integriteit van die Afrikaanse letterkundige korpus soos dit in die Afrikaanse literatuurgeskiedskrywing beslag gekry het, word dus glad nie aangetas nie. Die 'verskuiwing' wat hy bepleit, laat hom uiteindelik nog steeds binne die raanwerk van die diskursiewe formasie van die Afrikaanse letterkunde, veral omdat hy die konsep van die 'teks' (die korpus Afrikaanse letterkundige tekste) nie werklik grondliggend wysig nie.

In 'n sckere opsig is die resultaat van Coetzee se benadering ook 'n verdere verskraling van die Afrikaarse letterkundige tradisie want 'die Afrikaanse letterkunde' word hierdeur weer wat dit vir die literatuurgeskiedskrywing van die Tweede Taalbeweging was: 'n kulturele ontwikkeling wat in 1875 met die stigting van die Genootskap van Regte Afrikaners begin het. Alhoewel die heroriëntering wat hierdie benadering vermag het, nie onderskat moet word nie, bly dit 'n negatiewe benadering sonder ' $n$ beduidenswaardige konstitutiewe moment. Beoordeel in die lig van die probleem soos hierbo uiteengesit, skiet dit emstig tekort.

Van Vuuren se voorstel staan in hierdie opsig op stewiger grond, alhoewel sy op die oog af veel met Coetzee in gemeen het, soos blyk uit die volgende aanhaling:

As so ' $n$ nuwe literatuurgeskiedenis kan wegbreek van strukturele studies en estetiese isolasie, as dit ook die ruimte kan skep vir al die verskillende diskoerse in die Suid-Afrikaanse situasie, dan kan dit 'n bevrydende rol speel (Van Vuuren, 1991:66).

Sy identifiseer die probleem van die bestaande Afrikaanse literatuurgeskiedskrywing ook as 'n (diskursiewe) afgeslotenheid. Volgens haar is dit egter nie uitsluitlik 'n politieke kwessie nie, eerder die gevolg van 'n sekere literêr-teoretiese benadering:

Solank die literatuurgeskiedskrywer strukturalisties gerig bly, en die sosiohistoriese konteks negeer, bly ons sit met die dilemma van 'n teksgerigte, afgeslote literatuurgeskiedskrywing (Van Vuuren, 1991:65).

Die konsepsie van die probleem op hierdie manier as literêr-krities van aard, lei daartoe dat ook die oplossing op literêr-kritiese terrein gesoek word: sy bepleit 'n vergelykende leser- of resepsiegerigte benadering binne 'n Suid-Afrikaanse raamwerk (Van Vuuren, 1991:65, 68).

Binne die opset van hierdie artikel is dit nie moontlik om aandag te skenk aan die voor- en nadele van 'n lesergerigte benadering nie. Met betrekking tot 'n letterkundebenadering op 'n Suid-Afrikaanse grondslag is dit egter wel moontlik on die volgende opmerking te maak. Op logiese gronde is daar nie fout te vind met die voorstel van 'n Suid-Afrikaanse raanwerk vir letterkundestudie in Suid-Afrika nie. Die voorgestelde ontkoppeling van die Afrikaanse letterkunde en Afrikaner- 
nasionalisme genereer trouens amper outomaties so 'n opsie. Dit is dan ook 'n opsie wat lewendig gehou moet word, veral op grond van die sentiment van 'n gemeenskaplike Suid-Afrikaanse identiteit wat daarin vervat is.

Die vraag wat in hierdie verband gestel kan word, is of so 'n opsie nie te veel, te gou is nie. Die vraag is soortgelyk aan die vrae wat rondom moedertaalonderwys gevra word, en wat in die geval van die literatuurstudie en -geskiedskrywing neerkom op die vraag of die begeerde Suid-Afrikaanse identiteit nie beter gedien sal word deur 'n gesonder en standvastiger Afrikaanse identiteit nie. Hierdie vraag herinner aan die gees waarin Botha (1991:5) betoog dat die koestering van die Afrikaanse literêre erfenis 'n bydrae kan lewer tot die groei van 'n nasionale letterkunde.

In hierdie artikel gaan dit dus om prioriteite, en in die geval van die Afrikaanse letterkunde is die betoog dat die rekonstruksie van die Afrikaanse letterkundige subjek voorrang moet geniet bo 'n Suid-Afrikaanse letterkundige identiteit. Die opname van die Afrikaanse letterkundige identiteit soos dit nou saamgestel is bimne die groter geheel van 'n Suid-Afrikaanse raamwerk, hou wesenlike gevare vir die Afrikaanse identiteit in. Daar hoef maar net gedink te word wat die opname van die byna uitsluitlik negatiewe beeld van die Afrikaanse letterkunde soos dié van Coetzee (1990), naamlik as totaal ondergeskik aan die Afrikanernasionalistiese politieke program, in 'n groter geheel vir die Afrikaanse letterkunde sal beteken. ${ }^{8}$

\section{6. 'n Alternatiewe Afrikaanse literatuurgeskiedskrywing}

Die Foucaultiaanse konsep, diskontinutteit, wat deel uitmaak van sy argeologiese visie waarna vroeer verwys is, bied 'n alternatief wat in hierdie verband met vrug geëksploiteer kan word. Wat dié konsep veral bruikbaar maak, is die bevraagtekening van geskiedskrywing in terme van 'n enkele teleologiese begin of oorsprong

Vir die geskiedskrywing van die Afrikaanse letterkunde beteken dit dat die dwang om die Afrikaanse letterkunde in terne van één begin te konsipieer of

8 'n Implikasic van 'n diskocrsamalitiese benadering tot die geskicdenis van dic Afrikaanse letterkunde wat nic in die studic ter sprake kom nic. moct in hicrdic verband genotecr word Hicrdic implikasic is naamlik dat so ' $\mathrm{n}$ benadering met betrekking tot dic verhouding tussen dic Afrikaanse lettcrkunde en Afrikancrnasionalisme nic uitloop op dic venwerping van dic Afrikaanse letterkundige tradisie as gehel nic, maar trouens 'n hecl nuwe perspekticf op en lecsmoontlikhede ten opsigte van die letterkunde skep. Hicrdie benadering generecr naamlik dic vraag hoc daar binne dic perke van die tradisie weerstand gebied is tecn dic nasionalisticse aansprake - aansprake wat vra vir dic herwinning van 'n imtern onderdrukte stem. Grobbelaar en Roos (1992) en Roos (1992a) is voorbeclde van so 'n perspekticf. 
voor te stel, wegval. Dit word dan moontlik om te dink dat die Afrikaanse letterkunde verskillende 'beginne' kon gehad het - in 1875, 1652, in Afrika, in Europa, in Genadendal, selfs in Indonesië.

Die taak van die literatuurgeskiedskrywer word hierdeur natuurlik veel meer gekompliseerd, want die 'werklike' verbande (nie slegs kontinuiteite nie, maar ook breuke en verskille) tussen verskillende oorspronge en ontwikkelingslyne moet vasgestel word. Belcher (1986) se studie van Griekwa-gesange kan in hierdie opsig as voorbeeld dien van die soort kompleksiteit wat so 'n benadering moet verwerk. Hy beskryf naamlik hoe daar in die geval van die Griekwa-gesangtradisie ' $n$ beweging is vanaf geskrewe letterkunde na 'n mondelinge tradisie, en dan weer terug.

Één moontlikheid wat argumentsonthalwe in hierdie verband met betrekking tot die 'begin' van die Afrikaanse letterkunde as dié belangrikste in die huidige tydsgewrig aandoen, hou verband met 'n tendens wat reeds as kenmerkend van die hedendaagse Suid-Afrikaanse literêre toneel aangedui is: Van Vuuren (1991: 67) verwys naamlik na ' $n$ "... behoefte aan empatie met die gevoelswêreld van die swart Suid-Afrikaners ...".

Dis natuurlik Elsa Joubert se Die swerfjare van Poppie Nongena (1978) wat onmiddellik in die gedagte skiet in hierdie verband. Maar dit is veral ná hierdie baanbrekerswerk dat die sentiment gedy en in ' $n$ verskeidenheid vorme en intensiteite verskyn. Om net 'n paar voorbeelde aan te stip: in Dalene Matthee se Fiela se kind (1985) aanvaar Benjamin/Lukas vir Fiela Komoetie as sy moeder en erken daarmee tegelykertyd sy emosionele verbondenheid aan die Khoi-erfenis; Lou de Wet in Engela van Rooyen se In die oog van die web (1992) herwin sy psigiese ewewig tydens 'n verblyf tussen ' $n$ groep Boesmans in die Kalahari; die oermoeder van Thomas Landman in André P. Brink se Die kreef raak gewoond daaraan (1991), die slawevrou Catharijn, is afkomstig vanaf Bo-Guineë, oftewel Senegal.

Die eksemplariese teks in hierdie verband, veral in soverre dit die onderwerp van die studie aangaan, is egter John Miles se Kroniek uit die doofpot (1991) waarin hierdie tendens ook struktureel neerslag vind. Roos (1992b) toon aan dat daar duidelike strukturele ooreenkomste in terme van narratiewe patrone is tussen hierdie roman van die laat-twintigste eeu en Khoi- en Boesmanvertellings, en die Europese sprokievorm. Die sein wat deur hierdie ooreenkomste gestuur word, is duidelik: die Afrikaanse letterkunde soos verteenwoordig in Kroniek uit die doofpot se wortels (of 'begin') lê (ook) in die Khoi- en Boesmankultuur - in die stories wat om vure vertel is en die ervarings wat op rotswande verewig is. Dit 
dui op (nog) 'n geskiedenis wat sonder verwyl 'n erkende deel van die Afrikaanse letterkunde moet word. 9

\section{Slot}

Uiteindelik is hierdie ekskursie meer as 'n draai deur die Atrikaanse literatuurgeskiedenis - dit is ook 'n lens waardeur 'n aspek van die kontemporêre Afrikaanse letterkunde wat nie verlore mag gaan nie, sigbaar word. Die kontemporêre Afrikaanse fiktiewe teks is in hierdie opsig die herout van die groot taak wat op die ander 'sektore' van die Afrikaanse letterkunde wag: on die bewussyn van die heterogeniteit van die Afrikaanse letterkunde te laat deursyfer na die 'sisteme' van die Afrikaanse letterkunde wat die kontemporêre Afrikaanse letterkundige teks nie kon bybly nie. Navorsing, die onderrig van Afrikaans. die literère kritiek en les bes, die geskiedskrywing moet maniere vind on gestand te doen aan die eise van 'n nuwe en komplekse letterkundige werklikheid

\section{Verwysings}

Antonissen, Rob $1965^{3}$ (1955) Ire Afrikamse letrerkumde van camang tot hede Kaapstad: Nasou

Belcher, R 1986 From Literature to Oral Tradition and Back the Griqua Case history In Whitaker, Richard \& Sienaen, Edgard (eds) Oral Tradition and literacy. ('hangeng Iisions of the World (Selected Conference Papers, University of Natal, July 1985) Durban: Natal University Oral Documentation and Rescarch Centre p 261-269

Beicher, R 1988 Afrikaans - A Reappraisal Intreerede, Universiteit van Bophuthatswana. 16 Aug 1988

Botha, Elize 1986 Werkswinkel oor aspekte van literère geskiedskrywing In Swid-Afrikaanse Vereniging vir Algemene Literatmmruetenskap. Kongresreferale IT Pretoria : SAVAL p. 67-81.

Botha, Elize 1988 'n Herevaluering van benaderings tot geskied-en kroniekskrywing In Wiehahn, Rialette \& Roodt, PH (reds) Teks en kendens. Ierrigtinge van die 1986Hoofkongres wan die Afrikatanse letherkundevereniging Hillcrest : Owen Burgess p 1-6

Botha, Elize 1991 Literatore: kuratore? Sitlet, 3(2):1-6.

Brink, André P 1991. Die kreef rack gewoomd dacracm Kaapstad : Human en Rousseau Cloete, T.T (red.) 1980. Dic Afrikcumse liferummerederl Sesigg Kaapstad : Nasou

Cloete, T.T 1982 Literêre geskiedskrywing. Ty'dskrif vir (jeestessuetenskaple, 22(2) 141-152

Coetser, A 1992. Niemoedertaallesers en neigings in die Afrikaanse letterkunde Referaat gelewer by Mini-kongres, Dept Afrikaans, Universiteit van Transkei, 8 Okt 1992

Coetzee, Abel 1960 (1953) Dic Afrikaanse volkskulmur. Inleiding lot die shudie van volkskunde Kaapstad: A A Balkema

9 Miskien is so 'n ontwikkeling deel van wat $N$ P Van Wik Loun reeds in 1959 net die volgende woorde in dic voorutsig gestel het: "Afrikaans is dic taal wat vir Wes-Europa en Afrika verbind: dit suig sy krag uit die twee bronne, dit vorm 'n brug tussen die groot helder Weste en dic magiese Afrika - dic soms nog so on-helder Afrika: hulle is albei groot magte. en wat daar groots aan hulle vereniging kan ontspruit - dit is miskien wat vir Afrikaans voorlî om tc ontdck" (Louw, 1963:154) 
Coetzee, Abel \& Hattingh, S.C. 1951. Die Afrikaanse letterkunde. Rigtingslyne en hooglepunte. Johannesburg : Voortrekkerpers

Coetzee, Ampie 1990. Letterkunde en krisis. '" Honderd jaar Afrikaanse letterkunde en Afrikaner-nasionalisme. Bramley: Taurus

Conradie, Elizabeth 1934. Hollandse skrywers wit Suid-Afrika. 'n Kullmurhistoriese studie. Deel I (1652-1875). Kaapstad : HAUM

De Jong, Marianne 1989. 'n Ander Afrikaanse letlerkunde. Marxistiese en sosiaalgerigle teksopvattings in Afrikaans Pretoria : Raad vir Geesteswetenskaplike Navorsing.

Dekker, G. $1937^{2}$ (1934) Afrikaanse literaluurgeskiedenis. Kaapstad : Nasionale Pers

Du Plessis, L.T. 1986 Afrikaans in beweging. Bloemfontein : Patmos

Du Toit, S J 1909. Geskidems fan di Afrikaanse Taalbeweging. Paarl : Paarl Drukpers.

February, V.A. 1991. Laat het ons ernst wezen. Die verhouding Afrikaans-Nederlands Intreerede. Universiteit van Wes-Kaapland, 25 Sept 1991

Foucault, Michel 1972. The Archaeology of Knowledge London: Tavistock (Vertaling van $L$ Archéology du savoir, 1969. Parys : Editions Gallimard.)

Foucault, Michel. 1977. Language, Counter-menory, Practice. Selected Fssays and Interview's New York: Cornell University Press

Foucault, Michel 1980. Power Knowledge. Selected Interview's and Other Writings 19721977. Sussex: The Harvester Press

Gerwel, GJ 1983. Literatumr en apartheid. Konsepsies van 'gekleurdes' in die Afrikaanse roman tot 1948. Kasselsvlei : Kampen

Gray, 1986 Stephen 1986. The Praxis of Comparative Theory In: Sind-Afrikaansc Lereniging vir Algemene Literatmuruetenskap. Kongresreferate V7 Pretoria SAVAL p. 67-81

Grobbelaar, Mardelene \& Roos, Henriette 1992 Eugene N. Marais - estetisis en dekadent? Tydskrif vir Letrerkunde, 30(4) 64-74

Gouws, Thomas 1992. Paradigms Lost Sense-making Fictions in the Africanisation of Afrikaans Intreerede, Universiteit van Bophuthatswana, 5 Maart 1992

Jordaan, Jean 1993 Daar is tog method in the madness. (Resensie van Koos Kombuis se Afrikaans my darling.) Die Suid-Afrikaan, 43:18-19.

Joubert, E 1978. Die swerfjare van Poppie Nongena. Kaapstad: Tafelberg

Kannemeyer, J C. 19842 (1978) Geskiedenis van die Afrikaanse literatuur. Band I. Pretoria Academica

Kombuis, Koos (s.a.) ${ }^{2}$ Afrikaans my darling. Durban : Dirextion-X.

Louw, N.P Van Wyk 19632 Vermusing in die prosa. Grepe wit ons Afrikaanse ervaring Kaapstad : Human \& Rousseau

Macdonell, Diane 1986. Theories of Discourse. An Introduction. Oxford : Basil Blackweil

Malan, Charles (red) 1984 SA Literature Research SA letterkundenavorsing: Report on a Research Simposium Verslag van 'n navorsingsimposium. Pretoria : Raad vir Geesteswetenskaplike Navorsing

Malan, Charles 1986. Methodological Considerations for an Indigenous Historiography/Metodologiese oorwegings vir 'n inheemse historiografie In: Swid-Afrikaanse Vereniging vir Algemene Lileratumurefenskap. Kongresreferate LT. Pretoria : SAVAL p 58-66

Malan, Charles 1990 Literatuurgeskiedenis as 'n Suid-Afrikaanse kulturele diskoers In: Malan, Charles \& Jooste, G.A (reds.) Onder andere. Die Afrikaanse lellerkunde en kulmirele komekste. Pretoria : Universiteit van Suid-Afrika p. 27-42.

Matthee, Dalene 1985 Fiela se kind Kaapstad: Tafelberg

Miles, John 1991. Kromiek wit die doofpot. Polisieroman Bramley: Taurus

Nethersole, Reingard 1987. Literary History after Foucault? Journal of Literary Sindies, 3(2) $1-11$ 
Nienaber, P J. $19600^{2}$ (1951) Perspektief en profiel. 'n Cieskiedenis van die Afrikuanse letterkunde. Johannesburg: Afrikaanse Pers-Boekhandel

Nienaber, P J. 1965 Rapier en kmuppel. 'n Bundel letterkundige polemicke Kaapstad Nasionale Boekhandel

Nienaber, P. J. \& Nienaber, G.S. 1941 Geskicdenis van die Afrikansie lenerkunde Pretoria : J.L. van Schaik.

Olivier, Gerrit. 1987. Die 'in memoriam' van 'n vergange era. Die Sind-Afrikaan, 9:35-37

Olivier, Gerrit 1989. J C. Kannemeyer. D J Opperman en die tradisie Tydskrif irir Lcullerkunde, 27(2) 108-113.

Opperman, DJ 1939. Wanneer begin die Afrikaanse letterkunde? Dic Huisgenoor:29, 55, 57, Febr. 3

Pienaar, E.C $193 \mathrm{Ia}^{4}$ (1925) Taal en poesie van die Twede Afrikaanse Taalbeweging Kaapstad : Nasionale Pers.

Pienaar, E.C 1931b. Na 50 jaar In Nederlund-Zuid-Afrika. (iedenkboek witgegeven door de Nederlandsch Zuid-Afrikuansche Vereeniging, bij gelegenheid van haar vijfig-jarig bestaan Amsterdam De Bussy. p. 211-220.

Roos, Henriette 1992a. Volkskuns en fin de siecle. Perspektiewe op parallele tendense in die Vlaamse en Afrikaanse prosa Literator, 13(2):4l-54

Roos, Henriette 1992b. Die voorgeskiedenis van 'n dokumentêre roman John Miles se Krormek uit die doofpot. Referaat gelewer by ALV-kongres, Universiteit van Stellenbosch, 1-3 Okt 1992.

Schoonees, P.C. $1927^{2}$ (1922) Die prosa van die Turede Afrikaanse Beneging Pretoria JH de Bussy.

Van Niekerk, Lydia $1920 .^{2}$ (1916) De eerste Afrikaanse Taalheweging en letlerkmudige voorthrengselen. Kaapstad: De Nationale Pers

Van Rensburg. F. I.J 19712 (1963) Die smal baam. Aspekte en figure uit die onwikkelingsgang van die Afrikaunse letterkunde. Kaapstad: Tafelberg.

Van Rooyen, Engela 1992. In die oog vandie web. Kaapstad: Tafelberg.

Van Vuuren, Helize 1991 Afrikaanse of Suid-Afrikaanse letterkunde? ' $n$ Kritiese kyk na die Kannemeyer- en Coetzee-modelle van Afrikaanse literatuurgeskiedskrywing Stilet, 3(2) 63-70

Von Wielligh, G.R $1922 .^{2}$ (1917) Lerste skrywers, of Laaste stem en naklank wit die (jenootskap van Reghe Afrikaners. Pretoria : J L van Schaik.

Von Wielligh, G R 1925. Baambrekerswerk. of Die lefterkumdige. kulmurele e'n politicke betekenis ram die (Genootskap) ran Regle Afrikaners. Pretoria J L van Schaik

Willemse, Hein s a. Neigings en opvattinge by jonger Afrikaanse skrywers - 'n voorlopige verkenning In: Smith, Julian F, Van Gensen, Alwyn \& Willemse, Hein (reds ) Swart Afrikaanse skiyu'ers. I'erslag van 'n simposium gehou by die Universiteil van Wes-Kaapland, 2627 April 1985. Bellville : Universiteit van Wes-Kaapland p. 69-76.

Willemse, Hein 1990. Die skrille sonbesies: Emergent Black Afrikaans Poets in Search of Authority In: Trump. Martin Rendering Things Visible. Liscons on South African literary Cu/ture Johannesburg : Ravan p 367-401

Willemse, Hein 1992. "Ik is onbekend, ma ik is een van de ras so moet my nie veracht nie": Die beeldvorming van Piet Uithalder in die A P O (1909-1922) Referaat gelewer by ALV (Afrikaanse Letterkunde Vereniging) Kongres, Universiteit van Stellenbosch, 1-3 Oktober 1992.

Young, Roben 1990 Whwe Mythologies. Writing History and the West. London : Routledge.

\section{Universiteit van die Transkei}


